7) засобів контролю навчальної діяльності та оцінювального інструментарію.

Отже, моделювання як метод наукового дослідження дозволяє поєднати емпіричне i теоретичне в педагогічному дослідженні. Емпіричний рівень спостережень - пряме спостереження, експеримент, факти практики. Теоретичний побудова логічних конструкцій і наукових абстракцій. Отже, моделювання як засіб дослідження сприяє переведенню безсистемних знань у систему і має аналізуючі та синтезуючі функції. До основних етапів педагогічного моделювання належать: постановка завдання (мети), вибір або створення моделі, вивчення моделі, змістова інтерпретація результатів дослідження. Основна вимога до такої моделі: простота i адекватність. На основі обраної моделі проводиться педагогічний експеримент задля вивчення iї ефективності. Результати експерименту обробляються за допомогою статистичного методу. Під час оброблення результатів дослідження вибирається математична модель представлення педагогічного явища 3 урахуванням його специфіки. Практична та пізнавальна цінність такого моделювання полягає в адекватності аспектам об'єкта, що вивчається, та врахуванні принципів моделювання: наочності, визначеності, об'єктивності.

\title{
Література
}

1. Архангельский С. М. Лекции по теории обучения в высшей школе / С. М. Архангельский. - М. : Высш. шк., 1974. - 384 с. 2. Белл Д. Грядущее постиндустриальное общество. Опыт социального прогнозирования / Даниел Белл. M. : Academia, 2004. - 944 с. 3. Бібік Н. Компетентнісний підхід у презентації освітніх результатів / Н. Бібік // Школа першого ступеня: теорія і практика: зб. наук. праць Переяслав-Хмельницького держ. пед. ун-ту ім. Григорія Сковороди. - Вип. 10.Переяслав-Хмельницький, 2004. - С. 157-163. 4. Бондар С. П. Компетентність особистості - інтегрований компонент навчальних досягнень учнів / С. П. Бондар // Біологія і хімія в школі. - 2003. -№ 2. - С. 8-9. 5. Ващик Т. І. Моделювання у навчально-виховному процесі вищої школи / Т. І. Ващик // Нові технології навчання. К. : НМЦВО, 2005. - Вип. 41. - С. 147-158. 6. Дахин А. Н. Педагогическое моделирование: сущность, эффективность и неопределенность / А. Н. Дахин // Школьные технологии. - 2002. - № 2. - С. 62-67. 7. Зязюн І. А. Краса педагогічної дії:[навч. посібн.] / І. А. Зязюн. - К. :Українсько-фінський інститут менеджменту і бізнесу, 1997. - 302 с. 8. Липский И. А. Социальная педагогика: Методологический аналіз: [монографія] / И. А. Липский. - М. : Сфера, 2004. - 320 с. 9. Лобашев В. Д. Структурный подход к моделированию ведущих элементов процесса обучения/ В. Д. Лобашев // Инновации в образовании. - 2006. - № 3. - С.99-111. 10. Макєєва I. В. Роль семінарського заняття у підготовці фахівця і методика управління дискусією / І. В. Макєєва // Радянська педагогіка. - М. : Освіта. - 2003. - № 5. - С. 61. 11. Панфілов М. А. Знаково-символическое моделирование учебной информации в вузе / М. А. Панфилов // Педагогика. - 2005. - № 9. - С. 51-56. 12. Рудницька О. П. Педагогіка загальна та мистецька:[навч. посібн.] /О. П. Рудницька. - К. : Інтерпроф, 2002. - 270 с. 13. Фридман Л. М. Наглядность и моделирование в обучении / Л. М. Фридман. - М. : Знание, 1984. - 80 с. 14. Штофф В. А. Моделирование и философия / В. А. Штофф. - М. : Наука, 1996. - 304 с.

УДК 377.131 .14

Тетяна Сердюк

\section{НЕГАТИВНІ ЧИННИКИ ЗАСТОСУВАННЯ ГРУПОВИХ ФОРМ ОРГАНІЗАЦЇ̈ НАВЧАЛЬНО-ПІЗНАВАЛЬНОЇ ДІЯЛЬНОСТІ СТУДЕНТІВ}

Сердюк Т. В. Негативні чинники застосування групових форм організації навчально-пізнавальної діяльності студентів. 
У статті здійснено аналіз негативних чинників, які можуть супроводжувати застосування групових форм навчально-пізнавальної діяльності в навчальновиховному процесі, розкрито можливі шляхи їх запобігання або подолання.

Ключові слова:групова поляризація, фасилітація, групове мислення, соціальна ледачість.

Сердюк Т. В. Негативные факторы применения групповых форм организации учебно-познавательной деятельности студентов.

В статье представлен анализ негативных факторов, которые могут сопровождать использование групповых форм организации учебно-познавательной деятельности в учебно-воспитательном процессе, раскрыты возможные пути их предупреждения или преодоления.

Ключевые слова:групповая поляризация, фасилитация, групповое мышление, социальная лень.

Serduk T. V. Negative factors applying group forms of teaching and learning of students.

The author is analysing negative factors which can accompany the use of group forms of organization of educational-cognitive activity in an educational process, she is offering the possible ways of it warning or overcoming.

Keywords: group polarization, falicitation, group thought, social laziness.

На сучасному етапі розвитку вітчизняної системи освіти спостерігається посилення цікавості науковців, педагогів-практиків до особливостей використання в навчально-виховному процесі групових форм організації навчально-пізнавальної діяльності. Констатуємо, що вони характеризуються підвищенням якості навчальнопізнавальної діяльності, пізнавального рівня самостійної діяльності осіб, які навчаються, здійсненням диференційного підходу до навчання, ефективністю в засвоєнні нового навчального матеріалу і закріпленні вивченого.

Проблемам використання групових форм організації навчально-пізнавальної діяльності присвячені роботи М. Виноградової, В. Дьяченка, В. Котова, Х. Лийметса, Г. Ложкіна, С. Маргуліса, К. Нор, І. Первіна, В. Онищука, В. Рубцова, І. Чередова, Г. Ярошенко.

X. Лийметс як основну ознаку групових форм організації навчально-пізнавальної діяльності визначає спільну узгоджену діяльність осіб, які навчаються за відсутності постійного прямого контакту з педагогом [2]; О. Ярошенко трактує таку форму як досягнення спільної мети шляхом спільної діяльності членів невеликих за складом груп, що діють у межах класу [9]; на думку В. Онищука, - це спільні зусилля навчальних груп щодо вирішення навчальних завдань [7].

У цілому мала навчальна група є колективним суб'єктом, тобтовзаємопов'язана та взаємозалежна група осіб, які виконують спільну діяльність, основними характеристиками якого $є$ взаємозв'язок та взаємозалежність індивідів у групі, спільна активність і здатність до групової саморефлексії.

Г. Ложкін наводить такі основні характеристики колективного суб'єкта діяльності, ототожнюючи це поняття 3 субстантом «колектив як суб'єкт»: 1) спрямованість до основної мети діяльності; 2) взаємозв'язок та взаємозалежність між членами колективу; 3) діяльне ставлення до спільної праці; 4) визначеність взаємного розподілу функцій та відповідальності; 5) узгодженість дій членів колективу; 6) організованість та керованість; 7) здатність досягати запланованого результату [4].

Глибина та характер впливу групи на кожного iї члена визначається, 3 одного 
боку, індивідуально-психологічними та соціальними характеристиками суб'єкта (рівнем інтелектуального розвитку, вольовими якостями, спрямованістю особистості, цілями та мотивами її діяльності, статусом у групі, рольовою поведінкою та життєвою позицією), а з іншого боку, - психологічним кліматом, який існує у групі, характером міжособистісних стосунків.

На думку радянських психологів, визначальними ознаками інтегрованості осіб до групи є згуртованість, організованість, спрацьованість, співучасть.

Усі позитивні аспекти навчання в умовах спільної діяльності неодноразово розкривалися в науковій педагогічній і психологічній літературі.

Метою статті є аналіз тих негативних чинників групової діяльності осіб, які навчаються, з якими може зіткнутися педагог під час її застосування.

Кожний педагог-практик, який використовує групові форми навчальнопізнавальної діяльності, має враховуватиті негативні аспекти спільної діяльності, які становлять загрозу для успішного виконання навчально-виховних завдань, що ставить перед собою викладач.

Необхідною умовою існування будь-якої групиє норми як регуляторна основа діяльності групи в цілому і окремих їі членів. Норми групи, з одного боку, становлять правила поведінки членів групи, а 3 іншого- виражають колективну думку. Дотримання норм забезпечує передбачуваність поведінки індивідів, обмеження їхніх егоїстичних прагнень, корекцію їхніх дій відповідно до інтересів соціальних конструктів. I навпаки, зневажання нормами призводить до безладу, хаосу та ліквідації групи. Тому задля самозахисту та самозбереження будь-яка група негативно ставиться до тих суб'єктів, які діють усупереч загальновизнаним нормам. «Білі ворони», дисиденти стають ізгоями, група їх відсторонює. Безкомпромісна обструкція порушників групових норм уявляється загрозливим явищем для існування навчальної групи. Неприйняття перетворень, нестандартних ідей призводить до консервації і догматизації оцінок, настанов, засобів, процедур, що використовуються групою в іï діяльності, та, в кінці кінців, до розпаду групи. Отже, як нехтування груповими нормами, так і їх абсолютизація є деструктивними явищами в життєдіяльності будьякого соціального утворення.

Норми, залежно від їх характеру, напрямку дії (каральний або заохочувальний), рівня (абсолютні та конкретні) диференційовано впливають на поведінку кожного індивіда. На думку Б. Ананьєва, цей вплив має чотири рівні. На першому рівні норми не збігаються 3 внутрішньою мотиваційною структурою індивіда, тому вони виконують роль зовнішнього регулятора поведінки та не гарантують адекватності поведінки. На другому рівні спостерігається часткове засвоєння норм, що зумовлює їх перетворення на внутрішні мотиви та регуляцію поведінки індивіда. Третій рівень характеризується поєднанням дій соціальних норм 3 особистісною мотивацією та поведінкою. На четвертому, найвищому, ріні формується тотожність соціальних норм та особистісних мотивів й потреб, що визначає стійку регуляцію поведінки та дій індивіда [1].

Серед досліджень нормативної поведінки найбільшу увагу науковців привертає феномен конформізму, або феномен групового тиску. Індивід, формально погоджуючись 3 думкою більшості, не обов'язково приймає іiі як свою. Тому конформизм, тобто пасивне прийняття групових норм, покірне схиляння перед думкою більшості $є$ явищем, яке загрожує ефективності колективної навчальної роботи. При цьому необхідно зазначити, що саме особи, які перебувають на віковому відрізку ранньої юності, відрізняються найменшим відсотком конформності [2]. 
Викладач може зіткнутися 3 загрозою виникнення феномену групової поляризації, під яким розуміється «зрушення до екстремальності думок після проведення групової дискусії» [6, с. 121]. Цей термін був запропонований С. Московічі та М. Заволлоні, які зауважили, що групова дискусія, як правило, посилює середню тенденцію членів групи, при цьому під час групових обговорень особи виявляють схильність до більш крайніх позицій, ніж ті, 3 яких вони починали дискусію, що призводить до формування двох полярних позицій, між якими неможливий компроміс. Виникнення цього явища дослідники пов'язують 3 орієнтацією суб'єктів на соціальне порівняння, тобто постійне порівняння себе зі всіма членами групи задля утримання своєї позиції відносно групи.

Поляризаційний ефект, як розкол групи за ознакою наявності протилежних думок, негативно впливає на процес прийняття загального рішення та на продуктивність діяльності в цілому. Зниження рівня групової поляризації можна досягти в результаті формування адекватної та стійкої самооцінки групи, забезпечення максимальної рівності впливу членів групи на прийняття рішень, незалежно від групового статусу. У процесі запобігання виникнення групової поляризації викладачеві слід прагнути досягнення протилежного явища- феномену групової нормалізації, тобто такого результату дискусії, коли «протилежні погляди, навіть екстремальні позиції, згладжуються й набувають характеру усередненої думки» [8, с. 135].

Близьким за своєю сутністю до феномену полярізації групи $є$ феномен групового мислення, або групомислення. Це явище було виявлено І. Дженісом у процесі аналізу групових рішень, що мали негативні наслідки. За його визначенням, групове мислення це режим мислення, який виникає у членів групи в тому випадку, коли пошуки спільного рішення стають настільки домінуючими для групи, що вона схильна ігнорувати реалістичні оцінки альтернативних методів дій [10]. Задля запобігання цьому явищу викладачеві слід особливу увагу приділяти поведінці лідерів, стимулювати кожного члена колективу до формування та захисту власної точки зору.

Одним 3 небезпечних явищ, що виникають під час спільної діяльності, $\epsilon$ соціальна ледачість, яка означає схильність людей докладати менше зусиль в умовах групової діяльності, ніж під час діяльності індивідуальної. Це пояснюється недостатньою вмотивованістю в досягненні таких результатів, які є загальними для всіх членів колективу та не передбачають індивідуальної нагороди. Наявність групової відповідальності за результат діяльності автоматично зменшує відповідальність індивідуальну в умовах недостатньої особистісної зацікавленості. Окрім того, групова діяльність зменшує вплив такого мобілізуючого чинника, як зовнішня оцінка. Саме цей чинник та принцип змагальності зумовлюють виникнення феномену соціальної фасилітації, явища, протилежного соціальній ледачості. Під соціальною фасилітацією розуміють посилення домінантних реакцій у присутності інших людей, причому ці домінантні реакції посилюються, якщо суб'єкти впевнені, що їх дії оцінюються [5]. Побоювання негативної зовнішньої оцінки, насамперед 3 боку незнайомих людей, мобілізує індивіда, що дозволяє йому показувати більш якісні та високі результати. I навпаки, відсутність цього чинника призводить до послаблення самоконтролю i, як наслідок, погіршення результату. Задля подолання соціальної ледачості необхідно під час діяльності навчального колективу визначити критерії оцінювання індивідуальної діяльності кожного члена колективу, причому не тільки з боку викладача, але й з боку інших осіб, які навчаються, куратора академічної групи, представників адміністрації тощо. Уважаємо, що особливу увагу необхідно звертати на розвиток у студентів потреби в адекватній самооцінці своїх дій, що, в 
свою чергу, уможливлює формування такої фундаментальної характеристики людського життя, як рефлексія.

Аналізуючи хиби та недоліки групової роботи, слід зазначити, що їх наявність не $\epsilon$ контраргументом до твердження про необхідність активного використання групових форм роботи на заняттях та в позанавчальний час. Емпіричні дослідження довели, що групи можуть швидко приймати розумні рішення та можуть справлятися з цим краще, ніж їх найобдарованіші учасники. Знання про небезпеки, що можливі під час організації навчальної співпраці та взаємодій, необхідні кожному педагогові для успішного їх запобігання або подолання. За умов правильної організації навчання 3 використанням групових форм організації навчально-пізнавальної діяльності, формування у кожного члена групи усвідомлення цінності свого внеску у спільну справу, створення достатньої вмотивованості й зацікавленості в досягненні адаптивних результатів, урахування особливостей міжособистісних відносин, розподілу статусних ролей та створення сприятливого психологічного клімату можлива продуктивна діяльність навчального колективу.

Підсумовуючи аналіз проблем організації групових форм навчальнопізнавальної діяльності, маємо підкреслити те, що вона, на нашу думку, є найбільш ефективним механізмом створення навчального колективу, хоча сам колектив уявляється як якийсь ідеальний конструкт. Стверджувати актуальність цих питань нам дозволяють такі чинники. По-перше, групові форми організації навчальнопізнавальної діяльності є більш ефективними, ніж індивідуальні, про що свідчать і великий обсяг наукової психолого-педагогічної літератури, і власний педагогічний досвід. По-друге, такі характеристики колективу, як позитивний психологічний клімат, згуртованість, організованість, спрацьованість, статусна та рольова диференціація становлять вагомі інструменти ефективної соціалізації молодої людини, протидія антисоціальним упливам, умови формування таких значущих особистісних якостей, як толерантність, співчуття, почуття співпричетності та співдії.

Визначаючи головною метою навчально-виховного процесу формування творчої індивідуальності особи, яка навчається, ми розглядаємо використання групових форм організації навчально-пізнавальної діяльності як один 3 ефективних інструментів у цьому процесі. Наша позиція зумовлюється такими аргументами:

- продуктивна співпраця 3 іншими особами дозволяє людині досягти особисто значущих результатів, формує та розвиває в ній такі визнані загальнолюдські цінності та вміння, як толерантність, відповідальність за свої вчинки, вміння знаходити розумний компроміс та одночасно відстоювати свою позицію;

- збагачення контактів в умовах спільної діяльності зменшить негативний уплив психологічних чинників, що призводять до протиставлення себе суспільству, виникнення різноманітних форм антисоціального протесту;

- навички роботи в команді створять підгрунтя для більш щадного «влиття» до суспільства, усвідомлення індивідуумом себе як дієздатного, дієтворчого елемента суспільства;

- позитивний психологічний клімат, згуртованість, організованість, спрацьованість, статусна та рольова диференціація становлять вагомі інструменти ефективної соціалізації молодої людини, $\epsilon$ протидією антисоціальним впливам, умовами формування таких значущих особистісних якостей, як толерантність, співчуття, почуття співпричетності та співдії.

\section{Література}

1. Ананьев Б. Г. Человек как предмет познания / Борис Герасимович Ананьев. - 
СПб. : Питер, 2001. - 288 с. 2. Кричевский Р. Л. Психология малой группы: теоретический и прикладной аспекты / Р. Л. Кричевский, Е. М. Дубовская. - М. : Издво МГУ, 1991. - 207 с. З. Лийметс Х. Й. Групповая работа на уроке / Х. Й. Лийметс. М. :Знание, 1975. - 64 с. 4. Ложкін Г. Команда як колективний суб'єкт спільної діяльності / Григорій Ложкін // Соціальна психологія. - 2005. - № 5- С. 52-58. 5. Майерс Д. Социальная психология / David G. Myers; [перев с англ.]. -[2-е изд.]. Спб. : Питер, 1996. - 684 с. 6. Общение и оптимизация совместной деятельности /под ред. Г. Андреевой, Я. Яноушека. - М. : Изд-во МГУ, 1987. - 301 с. 7. Онищук В. О. Активізація навчання старшокласників / В. О. Онищук. - К. :Рад. школа, 1978. - 128 с. 8. Орбан-Лембрик Л. Е. Соціальна психологія :[підручник] : / Л. Е. ОрбанЛембрик. - К.: Либідь, 2006. - Кн. 2 : Соціальна психологія груп. Прикладна соціальна психологія. - 2006. - 560 с. 9. Ярошенко О. Г. Проблеми групової навчальної діяльності школярів: дидактико-методичний аспект:[монографія]/ О. Г. Ярошенко. - К. :Станіца, 1999. - 158 c. 10. Janis I. L. Groupthink: Psychological studies of policy decisions and fiascos (2nd ed.). - Boston: Houghton Mifflin, 1983. - 351 p.

Аліна Слюта

УДК 37.091.12:504+378.147.091.33-027.22

\section{ПЕДАГОГІЧНІ УМОВИ ФОРМУВАННЯ ПРОФЕСІЙНИХ УМІНЬ СТУДЕНТІВ-ЕКОЛОГІВ У ПРОЦЕСІ ВИРОБНИЧОӤ ПРАКТИКИ ДЛЯ ЗАСТОСУВАННЯ ЇХ У МАЙБУТНІЙ ДІЯЛЬНОСТІ}

Слюта А. М. Педагогічні умови формування професійних умінь студентівекологів у процесі виробничої практики для застосування їх у майбутній діяльності.

У статті узагальнено педагогічні умови формування професійних умінь студентів-екологів у процесі виробничої практики для застосування їх у майбутній діяльності. Автор наголошує на необхідності підвищення педагогічних вимог до якості професійної підготовки фахівців-екологів.

Ключові слова:професійні вміння, виробнича практика, студенти-екологи, професійна діяльність, професійна підготовка.

Слюта А. Н. Педагогические условия формирования профессиональных умений студентов-экологов в процессе производственной практики для применения их в будущей деятельности.

В статье обобщены педагогические условия формирования профессиональных умений студентов-экологов в процессе производственной практики для применения их в будущей профессиональной деятельности. Автор обращает внимание на необходимость повышения педагогических требований к качеству профессиональной подготовки специалистов-экологов.

Ключевые слова:профессиональные умения, производственная практика, студенты-экологи, профессиональная деятельность, профессиональная подготовка.

Slyuta A. N. Pedagogical conditions of professional skills to students of environmental practices in the production process for use in their future activity.

The paper summarizes the pedagogical conditions of professional skills to students of environmental practices in the production process for use in their future professional activity. The author draws attention to the need to improve the quality of pedagogical conditions of training of environmental specialists. 